\title{
Metformin-Induced Lactic Acidosis in the Presence of Acute Renal Failure
}

\author{
R. Assan ${ }^{1}$, Ch. Heuclin ${ }^{1}$, D. Ganeval ${ }^{2}$, Ch. Bismuth ${ }^{3}$, J. George ${ }^{4}$, and J. R. Girard ${ }^{5}$ \\ ${ }^{1}$ Department of Diabetology, Hôtel-Dieu, Paris, ${ }^{2}$ Department of Nephrology, Hôpital Necker, Paris, \\ ${ }^{3}$ Department of Toxicology, Hôpital Fernand Widal, Paris, ${ }^{4}$ Department of Reanimation, Hôpital Henri Mondor, Créteil, \\ and ${ }^{5}$ Laboratoire de Physiologie du Développement, Collège de France, Paris, France
}

Summary. Lactic acidosis occourred in 6 metformintreated diabetic patients. Five of them had received 1.6 to $2.4 \mathrm{~g}$ metformin per day over a period of weeks or years. Acute renal failure, induced by i.v. pyelography, arteriography, or severe dehydration, preceded lactic acidosis by a few days and apparently precipitated it. The sixth patient had normal renal function prior to taking a massive overdose of metformin in an attempt at suicide. The metabolic pattern was very similar to that observed in phenformin-induced lactic acidosis: severe metabolic acidosis (pH: $7.02 \pm 0.95 ; \mathrm{HCO}_{3}^{-}: 6.3 \pm 0.9 \mathrm{mmol} / \mathrm{l}$; $\mathrm{PaCO}_{2}: 25 \pm 4 \mathrm{mmHg} ; \mathrm{PaO}_{2}: 110 \pm 19 \mathrm{mmHg}$ ); hyperlactataemia $(18.4 \pm 3.3 \mathrm{mmol} / \mathrm{l})$ and high lactate/pyruvate ratio $(51 \pm 5)$; high blood alanine $(2.82 \pm 1.10 \mathrm{mmol} / \mathrm{l})$; high 3-hydroxybutyrate $(15.8$ $\pm 3.3 \mathrm{mmol} / \mathrm{l})$ and high 3-hydroxybutyrate/ acetoacetate ratio $(26 \pm 10)$. Hypoglycaemia ( 25 to $60 \mathrm{mg}$ per $100 \mathrm{ml}$ ) was observed in 4 patients, in spite of high glucagon $(760 \pm 148 \mathrm{pg} / \mathrm{ml})$ and low insulin $(13 \pm 5 \mu \mathrm{U} / \mathrm{ml})$ levels. A guanidine substance was characterized in the plasma at concentrations 45 to $110 \mu \mathrm{g} / \mathrm{ml}$; it was similar to metformin and distinct from creatinine, according to chromatographic and other criteria; its concentration in the plasma decreased during dialysis, and the same substance appeared in the dialysis effluent. The treatment included massive alkalinization ( 710 $\pm 130 \mathrm{mmol} / 1 \mathrm{i}$. v. for $48 \mathrm{~h}$ ), plasma volume expanders $(5630 \pm 1000 \mathrm{ml} / 48 \mathrm{~h})$, forced-diuresis and/or dialysis, insulin $(30 \pm 10 \mathrm{U} / 48 \mathrm{~h})$ and glucose $(300$ $\pm 50 \mathrm{~g} / 48 \mathrm{~h}$ ). - It is concluded that: 1 . metformin, like other biguanides, can induce lactic acidosis; 2 . acute renal failure is a prominent causal factor; 3 . pharmacokinetics of metformin account for this fact since metformin cannot be inactivated by the liver (as distinct from phenformin) and is normally excreted by the kidney; 4 . accumulation of biguanide is suggested by guanidine assay in the plasma; 5. metformin should not be prescribed in the presence of renal failure.

Key words: Metformin, lactic acidosis, acute renal failure, blood alanine, pyruvate, 3-hydroxybutyrate, acetoacetate.

From the respective frequency of case reports in medical journals, it seems that metformin-induced lactic acidosis occurs far less frequently than with phenformin. We report 6 diabetic patients with a metformin-induced lactic acidosis, very similar in its clinical and metabolic patterns to that induced by phenformin.

\section{Methods}

All patients, hospitalized in various medical departments for several days or weeks prior to the occurrence of lactic acidosis, were admitted to an intensive care unit once the acute metabolic complication had developed. Collection of biological samples and assays for the circulating substrates and hormones were performed as previously published [1].

Metformin was assayed by a colorimetric method [2], slightly modified and tested for specificity [1-3]. This method is based upon the reaction of alphanaphthol-diacetyl with the guanidine group of metformin. Preparation of samples was as previously published $[1,2]$ and standard curves for metformin were conducted with metformin (Metformin- $\mathrm{HCl}$, Aron Inc., Paris, France) added to normal plasma. Possible interference with other drugs taken by the 
patients was investigated and the results were negative. Plasma from uraemic patients not treated with metformin did not react in the assay. Further characterization included thin-layer chromatography on Kieselguhr plates (Merck 5729) with chloroformmethanol-ammonia $(90 / 9.9 / 0.1 \mathrm{v} / \mathrm{v})$ as solvent and the alpha-naphthol-diacetyl staining reagent [4]; colorimetric reaction with $\mathrm{NaC} 10 \mathrm{M} / 10$ [5] and crystallization in the presence of sodium phenyltetraborate [5] were also performed.

\section{Case Reports}

Case 1. Male, diabetic, 49 years, $166 \mathrm{~cm}, 80 \mathrm{~kg} ; 2.4 \mathrm{~g} /$ day metformin was given for one week. Because of hypertension (170 $110 \mathrm{mmHg}$ ), spironolactone, furosemide, alpha-methyl-dopa and dihydralazine were also prescribed. Serum creatinine was 2.0 $\mathrm{mg} / 100 \mathrm{ml}$ and blood glucose $400 \mathrm{mg} / 100 \mathrm{ml}$. I.v. pyelography was performed and the patient became anuric on the following day; administration of metformin was continued for two further days. On admission (three days after the $i, v$. pyelography) the patient was hypothermic $\left(35.6^{\circ} \mathrm{C}\right)$ and anuric. Blood pressure was $65-40 \mathrm{mmHg}$, central venous pressure $9 \mathrm{mmHg}$ and heart rate $75 / \mathrm{min}$. Hypoglycaemia $(55 \mathrm{mg} / 100 \mathrm{ml}$ ) accompanied the metabolic acidosis and hyperlactataemia. Glucose ( $325 \mathrm{~g})$, insulin $(10 \mathrm{U})$, plasma volume expanders $(4000 \mathrm{ml})$ and sodium bicarbonate (425 mmol.) were rapidly administered and haemodialyses subsequently performed ${ }^{1}$. The patient improved rapidly and was discharged a fortnight later; serum creatinine at that time was 1.9 $\mathrm{mg} / 100 \mathrm{ml}$.

Case 2. Male, diabetic, 52 years, $94 \mathrm{~kg}, 170 \mathrm{~cm}$; metformin 2.4 $\mathrm{g} /$ day was given for 14 months. Hyperlipaemia and hypertension were also present and were treated with propranolol, clonidine, furosemide and clofibrate; serum creatinine, at that time, was 3.6 $\mathrm{mg} / 100 \mathrm{ml}$. I. v. pyelography was performed and the patient became anuric on the following day. The same dose of metformin was administered for a further 5 days; then lactic acidosis was diagnosed. On admission in the intensive care unit, the patient was deeply comatose, breathing rapidly ( 32 per minute) and relatively hypotensive $(140-80 \mathrm{mmHg}$ ); central venous pressure was $5 \mathrm{mmHg}$, mean pulmonary artery pressure: $8 \mathrm{mmHg}$, pulmonary capillary pressure: $5 \mathrm{mmHg}$. Administration of insulin $(30 \mathrm{U}$ ), glucose $(200 \mathrm{~g})$, plasma volume expanders $(3750 \mathrm{ml})$, sodium bicarbonate $(1500 \mathrm{mmol})$ and furosemide $(1300 \mathrm{mg})$ was combined with peritoneal dialysis. The patient recovered from lactic acidosis and acute renal failure, but died following a massive hemiplegia two months later.

Case 3. Female, diabetic, 67 years, $58 \mathrm{~kg}, 150 \mathrm{~cm}$. Metformin $(1.6 \mathrm{~g} /$ day $)$ was given over a period of 15 years with the recent addition of glibenclamide $10 \mathrm{mg} / 24 \mathrm{~h}$. Diabetes mellitus was associated with coronary artery disease and peripheral arterial disease: myocardial infarctions had occurred in 1970, 1973 and February 1975. When hospitalized (April 1975) serum creatinine was $2.0 \mathrm{mg} / 100 \mathrm{ml}$ and blood glucose $90 \mathrm{mg} / 100 \mathrm{ml}$. Aortography was performed and the patient became anuric within a few hours. Severe hypoglycaemia occurred $24 \mathrm{~h}$ later; the glibenclamide was stopped, but not the metformin. The patient remained semicomatose and anuric in spite of administration of plasma volume

\footnotetext{
1 The various treatments mentioned are those administered during the first $48 \mathrm{~h}$
}

expanders $(2300 \mathrm{ml})$ and furosemide $(330 \mathrm{mg})$. Blood pressure was $150-90 \mathrm{mmHg}$ and central venous pressure $2 \mathrm{mmHg}$. In spite of repeated haemodialyses, the metabolic acidosis rapidly worsened and a second hypoglycaemic episode occurred (25 $\mathrm{mg} / 100 \mathrm{ml}$ ). Serum creatinine at that time was $4.8 \mathrm{mg} / 100 \mathrm{ml}$. The metformin was stopped and haemodialyses were repeated. The patient recovered from acute renal failure and lactic acidosis, but died from myocardial infarction one month later.

Case 4. Female, 66 years, $76 \mathrm{~kg}, 170 \mathrm{~cm}$. Diabetes mellitus, high blood pressure and hyperlipaemia were diagnosed (1975) following a sudden left hemiplegia. Serum creatinine was $1.1 \mathrm{mg} / 100$ $\mathrm{ml}$ and fasting blood glucose $290 \mathrm{mg} / 100 \mathrm{ml}$. She was given metformin $1.6 \mathrm{~g} / \mathrm{day}$ for 10 months; administration of the drug was interrupted on several occasions because of gastric intolerance, then resumed. $240 \mathrm{mg}$ gentamycin per day was added because of an urinary infection. Acute gastroenteritis then induced severe dehydration and anuria. The patient was comatose and polypneic. Blood pressure was $120-90 \mathrm{mmHg}$, central venous pressure 3 $\mathrm{mmHg}$. Serum creatinine at that time was $3.0 \mathrm{mg} / 100 \mathrm{ml}$ and blood glucose $45 \mathrm{mg} / 100 \mathrm{ml}$. Administration of plasma volume expanders $(7000 \mathrm{ml})$, sodium bicarbonate $(560 \mathrm{mmol}$.) and furosemide $(325 \mathrm{mg})$ was followed by the restoration of urine flow; the patient progressively recovered from acidosis, hyperlactataemia and acute renal failure.

Case 5. Male, diabetic, 38 years, $60 \mathrm{~kg}, 170 \mathrm{~cm}$. Metformin 1.6 $\mathrm{g} /$ day was given for 6 weeks. He then took $24 \mathrm{~g}$ metformin plus phenobarbital and opipramol in an attempt at suicide. He was admitted to hospital $10 \mathrm{~h}$ later, deeply comatose, hypothermic (34.5) and anuric; blood pressure was $110-70 \mathrm{mmHg}$ and pulse rate $100 / \mathrm{min}$. Respiratory rate was $20 / \mathrm{min}$. in spite of a deep metabolic acidosis, presumably because of the associated phenobarbital intoxication; concentration of phenobarbital in plasma was $50 \mu \mathrm{g} / \mathrm{ml}$ on admission; ethanol, methanol and acetyl salicylic acid were not detectable. Serum creatinine was $0.8 \mathrm{mg}$ per $100 \mathrm{ml}$. Respiratory assistance was provided; peritoneal dialysis, sodium bicarbonate $(1260 \mathrm{mmol}$ ) and furosemide $(280 \mathrm{mg})$ were administered. The patient remained anuric, collapsed and died 30 $\mathrm{h}$ after admission. Serum creatinine was $3.0 \mathrm{mg} / 100 \mathrm{ml}$ before death.

Case 6. Female, diabetic, 65 years, $47 \mathrm{~kg}, 144 \mathrm{~cm} ; 1.6 \mathrm{~g}$ of metformin was given per day over a period of 15 years. Several episodes of gastroenteritis were followed by dehydration. When admitted, the patient was anuric, hypothermic and comatose. Blood pressure was $120-80 \mathrm{mmHg}$. Blood glucose was 60 $\mathrm{mg} / 100 \mathrm{ml}$; serum creatinine, which had been $3.1 \mathrm{mg} / 100 \mathrm{ml}$ some weeks earlier, was $7.5 \mathrm{mg}$ per $100 \mathrm{ml}$; sodium bicarbonate (600 mmol.), furosemide (500 $\mathrm{mg}$ ), plasma volume expanders $(6000 \mathrm{ml})$, glucose $(50 \mathrm{~g})$ and insulin $(20 \mathrm{U})$ were given. The patient recovered.

\section{Results}

\section{Precipitating Factors (Table 1)}

All patients had been treated with metformin for weeks to years. Overdosage, due to psychotic behaviour, occurred in patient $n^{\circ} 5$. Usual doses (1.6 to $2.4 \mathrm{~g}$ /day) had been given despite known chronic renal failure in patients $n^{\circ} 1,2,3,6$.

Acute renal failure was present, on admission, in 
Table 1. Precipitating factors in 6 patients with metformin-induced lactic acidosis

\begin{tabular}{|c|c|c|c|c|c|c|}
\hline Case $\mathrm{N}^{\mathrm{o}}$ & $\begin{array}{l}\text { Metformin } \\
\text { g/day }\end{array}$ & Cause of anuria & $\begin{array}{l}\text { Serum } \\
\text { creatinine } \\
\mathrm{mg} / 100 \mathrm{ml} \\
\text { prior to } \\
\text { anuria }^{\mathrm{a}}\end{array}$ & $\begin{array}{l}\text { Serum } \\
\text { creatinine } \\
\mathrm{mg} / 100 \mathrm{ml} \\
\text { on } \\
\text { admission }\end{array}$ & Associated diseases & Other drugs \\
\hline 1. & $\begin{array}{l}2.4 \\
8 \text { days }\end{array}$ & Pyelography & 2.0 & 6.8 & Mitral stenosis & $\begin{array}{l}\text { Dihydralazine } \\
\text { Spironolactone } \\
\text { Furosemide }\end{array}$ \\
\hline 2. & $\begin{array}{l}2.4 \\
14 \text { months }\end{array}$ & Pyelography & 3.6 & 9.6 & $\begin{array}{l}\text { Hypertension } \\
\text { Cardiac failure }\end{array}$ & $\begin{array}{l}\text { Propranolol } \\
\text { Clonidine } \\
\text { Furosemide } \\
\text { Clofibrate }\end{array}$ \\
\hline 3. & $\begin{array}{l}1.6 \\
15 \text { years }\end{array}$ & Arteriography & 2.0 & 4.8 & $\begin{array}{l}\text { Myocardial infarction } \\
\text { Limb arteriopathy }\end{array}$ & Glibenclamide \\
\hline 4. & $\begin{array}{l}1.6 \\
10 \text { months }\end{array}$ & $\begin{array}{l}\text { Gastroenteritis } \\
\text { Dehydration }\end{array}$ & 1.1 & 3.0 & Hypertension & Gentamycin \\
\hline 5. & $\begin{array}{l}1.6 \\
6 \text { weeks } \\
+24 \mathrm{~g} \\
\text { (overdose) }\end{array}$ & Shock & 0.8 & $0.8^{\mathrm{b}}$ & $\begin{array}{l}\text { Psychosis } \\
\text { Alcoholism } \\
\text { Peptic ulcer }\end{array}$ & $\begin{array}{l}\text { Opipramol } \\
\text { Phenobarbital } \\
\text { (overdose) }\end{array}$ \\
\hline 6. & $\begin{array}{l}1.6 \\
15 \text { years }\end{array}$ & $\begin{array}{l}\text { Gastroenteritis } \\
\text { Dehydration }\end{array}$ & 3.1 & 7.5 & Urinary infection & \\
\hline
\end{tabular}

a Samples for creatinine had been routinely collected a few days before the acute metabolic events

b Creatinine was $3.0 \mathrm{mg} / 100 \mathrm{ml} 24 \mathrm{~h}$ later

Table 2. Substrates and hormones in plasma on admission

\begin{tabular}{|c|c|c|c|c|c|c|c|c|c|c|}
\hline Case $\mathrm{N}^{\circ}$ & $\begin{array}{l}\text { Glucose } \\
\mathrm{mg} / 100 \mathrm{ml}\end{array}$ & $\begin{array}{l}\text { Lactate } \\
\mathrm{mmol} / 1\end{array}$ & $\begin{array}{l}\text { Pyruvate } \\
\mathrm{mmol} / \mathrm{l}\end{array}$ & $\begin{array}{l}\text { Alanine } \\
\mathrm{mmol} / \mathrm{l}\end{array}$ & $\begin{array}{l}\text { 3-Hydroxy- } \\
\text { Butyrate } \\
\mathrm{mmol} / \mathrm{l}\end{array}$ & $\begin{array}{l}\text { Aceto } \\
\text { acetate } \\
\mathrm{mmol} / \mathrm{l}\end{array}$ & $\begin{array}{l}\text { Free fatty } \\
\text { acids } \\
\text { mmol/1 }\end{array}$ & $\begin{array}{l}\text { Free } \\
\text { glycerol } \\
\text { mmol/l. }\end{array}$ & $\begin{array}{l}\text { Glucagon } \\
\mathrm{pg} / \mathrm{ml}\end{array}$ & $\begin{array}{l}\text { Insulin } \\
\mu \mathrm{U} / \mathrm{ml}\end{array}$ \\
\hline 1. & 55 & 7.2 & 0.13 & 1.32 & 23.0 & 0.52 & 0.72 & 0.080 & 565 & 5 \\
\hline 2. & 200 & 13.2 & 0.29 & 1.26 & 15.4 & 0.74 & 0.68 & 0.340 & 1200 & 15 \\
\hline 3. & 25 & 13.0 & & & & & & & & \\
\hline 4. & 45 & 20.0 & 0.50 & 0.91 & 17.5 & & 0.70 & 0.300 & 660 & 5 \\
\hline 5. & 270 & 39.0 & 0.60 & 7.80 & 7.2 & 0.74 & 0.42 & 0.680 & 612 & 26 \\
\hline 6. & 60 & 18.0 & & & & & & & & \\
\hline mean & 109 & 18.4 & 0.38 & 2.82 & 15.8 & 0.67 & 0.63 & 0.350 & 760 & 13 \\
\hline SEM & 41 & 3.3 & 0.10 & 1.10 & 3.3 & 0.07 & 0.07 & 0.123 & 148 & 5 \\
\hline \multicolumn{11}{|c|}{ Non diabetic controls $(8)$} \\
\hline mean & 77 & 1.1 & 0.110 & 0.45 & 0.016 & 0.118 & 0.310 & 0.096 & 95 & 16 \\
\hline SEM & 2 & 0.1 & 0.003 & 0.03 & 0.001 & 0.005 & 0.050 & 0.016 & 18 & 7 \\
\hline
\end{tabular}

all patients (Fig. 1). I.v. pyelography (patients $\mathrm{n}^{\circ} 1$ and 2), arteriography (patient $\mathbf{n}^{\circ} 3$ ) or acute dehydration induced by gastroenteritis (patients $n^{\circ} 4$ and 6) preceded the renal failure. Haemodynamics were not dramatically modified when lactic acidosis was diagnosed, except in patient $\mathbf{n}^{\circ} 1$. The time-relationship between the probable cause for anuria, then renal failure and the appearance of lactic acidosis suggests strongly that in patients $n^{\circ} 1,2,3,4,6$ anuria was not the consequence of lactic acidosis but its precipitating cause. In patients $\mathrm{n}^{\circ} 2$ and 6 , the first blood samples collected showed a sharp rise of blood lactate. In patient $\mathrm{n}^{\circ} 5$, the shock following overdosage of various drugs seems to have caused anuria and the rise of creatinine, which was initially normal.

A cardiopathy and/or a severe angiopathy were present in patients $\mathrm{n}^{\circ} 1,2,3,4$; diuretic or antihypertensive treatment had been recently started in patients $\mathrm{n}^{\circ} 1$ and 2 and gentamycin administered in patient $n^{\circ} 4$ : all possible adjuvant factors for a rise of serum creatinine and a decrease in renal excretion of metformin.

Liver function was normal in all patients includ- 


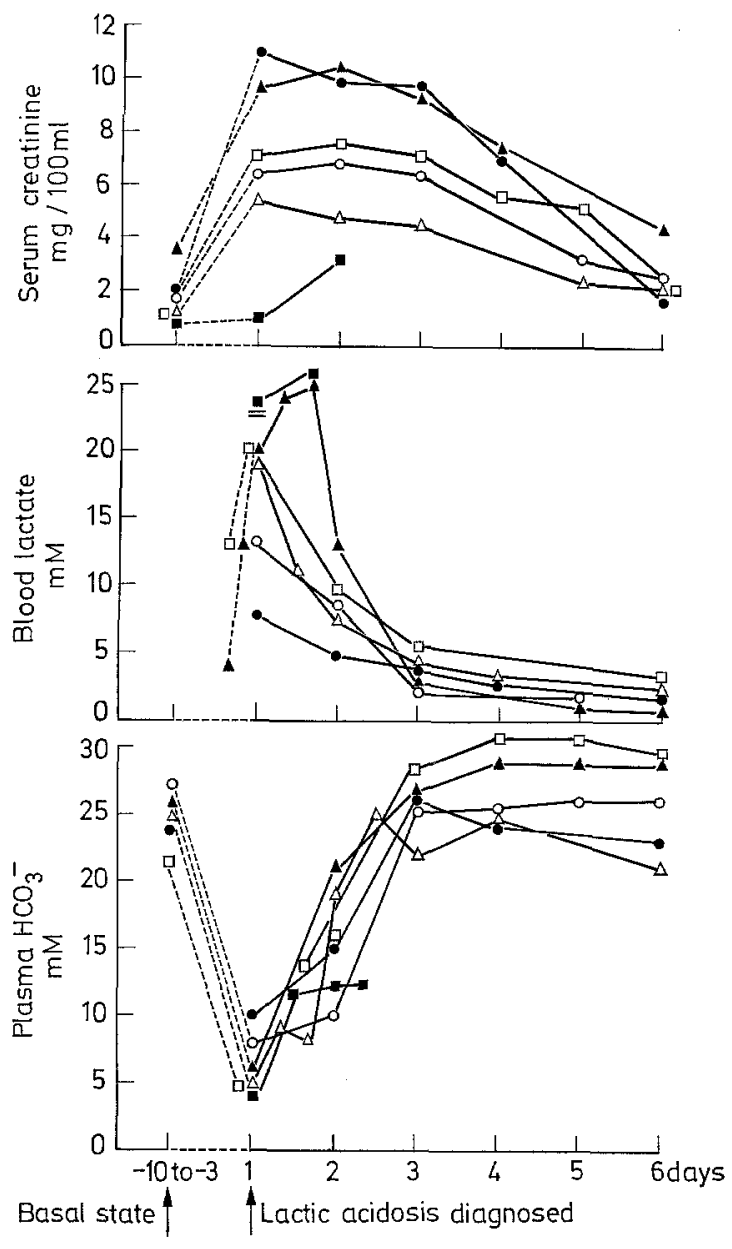

Table 3. Time-course of metabolic changes in patient 2 during the therapeutic period

\begin{tabular}{|c|c|c|c|c|c|}
\hline & \multicolumn{5}{|c|}{ Day Number } \\
\hline & 1 & 2 & 3 & 4 & 5 \\
\hline Blood glucose $(\mathrm{mg} / 100 \mathrm{ml})$ & 200 & 335 & 105 & 150 & 220 \\
\hline Lactate $(\mathrm{mmol} / \mathrm{l})$ & 13.0 & 24.0 & 13.0 & 3.2 & 1.2 \\
\hline Pyruvate $(\mathrm{mmol} / \mathrm{l})$ & 0.29 & 0.29 & 0.23 & 0.12 & 0.01 \\
\hline $\mathrm{L} / \mathrm{P}$ ratio & 45 & 83 & 56 & 26 & 13 \\
\hline Alanine (mmol/l) & 1.80 & 3.00 & 1.70 & 0.32 & 0.16 \\
\hline 3-hydroxybutyrate $(\mathrm{mmol} / \mathrm{l})$ & 16.0 & 13.2 & 3.1 & 0.2 & 0.2 \\
\hline Acetoacetate $(\mathrm{mmol} / \mathrm{l})$ & 0.76 & 0.54 & 0.11 & 0.02 & 0.02 \\
\hline Free fatty acids (mmol/l) & 0.72 & 0.28 & 0.38 & 0.40 & 0.40 \\
\hline Free glycerol $(\mathrm{mmol} / \mathrm{l})$ & 0.22 & 0.14 & 0.12 & 0.09 & 0.09 \\
\hline Glucagon $(\mathrm{pg} / \mathrm{ml})$ & 1200 & 820 & 520 & 610 & 400 \\
\hline Insulin $(\mu \mathrm{U} / \mathrm{ml})$ & 15 & 42 & 42 & 38 & 40 \\
\hline Growth hormone (ng/ml) & 1.0 & 1.2 & 1.8 & 1.2 & 1.2 \\
\hline Cortisol $(\mu \mathrm{g} / 100 \mathrm{ml})$ & 67 & 29 & 31 & 16 & 16 \\
\hline \multicolumn{6}{|l|}{ Treatment } \\
\hline Plasma volume expanders (ml) & \multicolumn{2}{|l|}{1250} & 2000 & \multirow[t]{4}{*}{500} & \\
\hline $\mathrm{NaHCO}_{3}$ i.v. $(\mathrm{mmol} / \mathrm{l})$ & 80 & 720 & 320 & & 375 \\
\hline Furosemide (mg) & 250 & 560 & 450 & & \\
\hline Glucose i.v. (g) & 100 & 100 & & & \\
\hline Insulin (units) & & 30 & 25 & & 20 \\
\hline Dialysis & \multicolumn{3}{|c|}{$\begin{array}{l}\text { Peritoneal } \\
\text { Dialysis }\end{array}$} & \multicolumn{2}{|c|}{ Haemodialysis } \\
\hline
\end{tabular}

Fig. 1. Time-relations between acute renal failure and the onset of lactic acidosis (LA). Initial values (prior to anuria and LA) were collected in the hospitalized patients a few days before the occurrence of anuria. Day $\mathrm{N}^{\circ} 1$ is defined by the diagnosis of lactic acidosis. Individual symbols and curves correspond to patients $\mathrm{n}^{\mathrm{o}} 1(\bullet), 2(\mathbf{\Delta}), 3(0), 4(\triangle), 5(\mathbf{\square})$ and $6(\square)$

Table 4. Associated factors in 8 published cases of metformin-induced lactic acidosis

\begin{tabular}{|c|c|c|c|c|c|}
\hline $\begin{array}{l}\text { Refer- } \\
\text { ences }\end{array}$ & & $\begin{array}{l}\text { Metformin dose } \\
\mathrm{g} / \text { day (duration) }\end{array}$ & $\begin{array}{l}\text { Cause for } \\
\text { renal failure }\end{array}$ & $\begin{array}{l}\text { Serum creatinine }(\mathrm{C} .) \\
\text { or blood urea }(\mathrm{U} .)\end{array}$ & $\begin{array}{l}\text { Associated } \\
\text { diseases }\end{array}$ \\
\hline (6) & & $2 \mathrm{~g}$; (4 days) & Glomerulosclerosis & C. $=5.0 \mathrm{mg} / 100 \mathrm{ml}$ & \\
\hline (7) & & $4.5 \mathrm{~g} ;(2$ years $)$ & Limb Surgery? & $\mathrm{U} .=130 \mathrm{mg} / 100 \mathrm{ml}$ & $\begin{array}{l}\text { Arteriopathy } \\
\text { Gangrene of toes }\end{array}$ \\
\hline (8) & $\begin{array}{l}\mathrm{N}^{\circ} 1 \\
\mathrm{~N}^{\circ} 2\end{array}$ & $\begin{array}{r}1 \mathrm{~g} ; \text {; (years) } \\
1.6 \mathrm{~g} \text {; (years) }\end{array}$ & $\begin{array}{l}\text { i.v. pyelography } \\
\text { cirrhotic hypovolaemia }\end{array}$ & $\begin{array}{l}\text { Not mentioned } \\
\mathrm{U} .=75 \mathrm{mg} / 100 \mathrm{ml}\end{array}$ & $\begin{array}{l}\text { Hypertension } \\
\text { Liver cirrhosis }\end{array}$ \\
\hline (9) & $\mathrm{N}^{\circ} 1$ & $1.6 \mathrm{~g} ;(7$ years $)$ & $\begin{array}{l}\text { Low molecular weight } \\
\text { Dextran i.v. }\end{array}$ & C. $=7.5 \mathrm{mg} / 100 \mathrm{ml}$ & \\
\hline & $\mathrm{N}^{\circ} 2$ & $1.6 \mathrm{~g} ;(5$ years $)$ & Unknown & C. $=5.5 \mathrm{mg} / 100 \mathrm{ml}$ & \\
\hline (10) & $\begin{array}{l}N^{\circ} 1 \\
N^{\circ} 2\end{array}$ & $\begin{array}{l}1.6 \mathrm{~g} \text {; (years) } \\
1.6 \mathrm{~g} ; \text { (years) }\end{array}$ & $\begin{array}{l}\text { Unknown } \\
\text { Cardiac failure }\end{array}$ & $\begin{array}{l}\text { Not mentioned } \\
\text { Not mentioned }\end{array}$ & Cardiac failure \\
\hline
\end{tabular}

ing $n^{\circ} 5$; in this patient an acute alcoholic intoxication was excluded by ethanol assay in plasma.

\section{Metabolic Study}

All patients exhibited, on admission, the metabolic criteria for severe metabolic acidosis: mean blood $\mathrm{pH} 7.02 \pm 0.95 ; \mathrm{HCO}_{3}^{-}: 6.3 \pm 0.9 \mathrm{mmol} / 1 ; \mathrm{PaO}_{2}$ : $110 \pm 19 \mathrm{mmHg} ; \mathrm{PaCO}_{2}: 25 \pm 4 \mathrm{mmHg}$.

The concentrations of circulating substrates and hormones on admission is shown in Table 2. Blood glucose level was low in 4 patients while the 2 others were hyperglycaemic. The high blood lactate concentration $(18.4 \pm 3.3 \mathrm{mmol} / \mathrm{l})$ was associated with high $\mathrm{L} / \mathrm{P}$ ratios $(51 \pm 5)$ and high blood alanine concentrations $(2.82 \pm 1.10 \mathrm{mmol} / \mathrm{l})$. Hydroxybutyrate level was elevated $(15.8 \pm 3.3 \mathrm{mmol} / \mathrm{l})$ and the ratio hydroxybutyrate/acetoacetate was higher than normal $(26 \pm 10)$. This hyperketonaemia contrasted 
with the moderate increase of free fatty acids $(0.63$ $\pm 0.07 \mathrm{mmol} / \mathrm{l}$ ). High glucagon values (mean: 760 $\pm 148 \mathrm{pg} / \mathrm{ml}$ ) were accompanied by normal or low insulin values (mean $13 \pm 5 \mu \mathrm{U} / \mathrm{ml}$ ). As expected from severely stressed patients, growth hormone and cortisol were high, respectively: $11.5 \pm 4.8$ $\mathrm{ng} / \mathrm{ml}$ and $44 \pm 12 \mu \mathrm{g} / 100 \mathrm{ml}$. The time-course of the metabolic disturbances is shown in Figure 2 and detailed for patient $\mathrm{n}^{\circ} 2$ in Table 3; blood lactate and alanine did not return to near-normal values before the 4th day of treatment; the decrease in 3hydroxybutyrate and free fatty acids occurred sooner. An alkaline overshoot was noted on the 4th or 5 th day in all the patients who recovered from lactic acidosis.

\section{Guanidine Derivative Results}

Plasma samples from patients $\mathbf{n}^{\circ} 1,2,4,5$ revealed high concentrations of an abnormal guanidine derivative ranging from 45 to $110 \mu \mathrm{g} / \mathrm{ml}$ (Fig. 3); this was not investigated in patients $n^{\circ} 3$ and 6 . Plasma from uraemic patients, not treated with metformin, plasmas from metformin-treated subjects with normal renal function, and control peritoneal dialysis fluid yielded undetectable values. Thin-layer chromatography demonstrated RF values identical to that of metformin and different from that of creatinine. The same substance was present in the effluent peritoneal fluid from patient $\mathbf{n}^{\circ} 2$. Repeated measurements demonstrated a progressive decrease in the plasma metformin level during the therapeutic course. Neutralized plasma extracts, in the presence of $\mathrm{NaClO} 0.1 \mathrm{M}$, gave the colorimetric reaction of metformin, with a maximal absorption at $380 \mathrm{~nm}$. Crystallization in the presence of sodium-phenyltetraborate yielded hexagonal crystals similar to those obtained with metformin.

\section{Discussion}

Only 8 case records of lactic acidosis associated with a metformin treatment exclusive of other biguanides have been published compared with near two hundred published cases of phenformin-associated lactic acidosis $[1,12-16]$. Data derived from [17] indicate that biguanide consumption in France, for 1975, was $92,054 \mathrm{~kg}$ metformin and $1,418 \mathrm{~kg}$ phenformin; assuming a mean daily intake of $2 \mathrm{~g}$ metformin or 0.1 $\mathrm{g}$ phenformin per patient, 165000 patients may have been on biguanide therapy in France that year: $76 \%$ of them on metformin and $24 \%$ on phenformin, a very different proportion from certain other countries [18, 19]. Metformin is approximately 20 times less active than phenformin [20]; this much lower hypoglycaemic potency is believed to be due
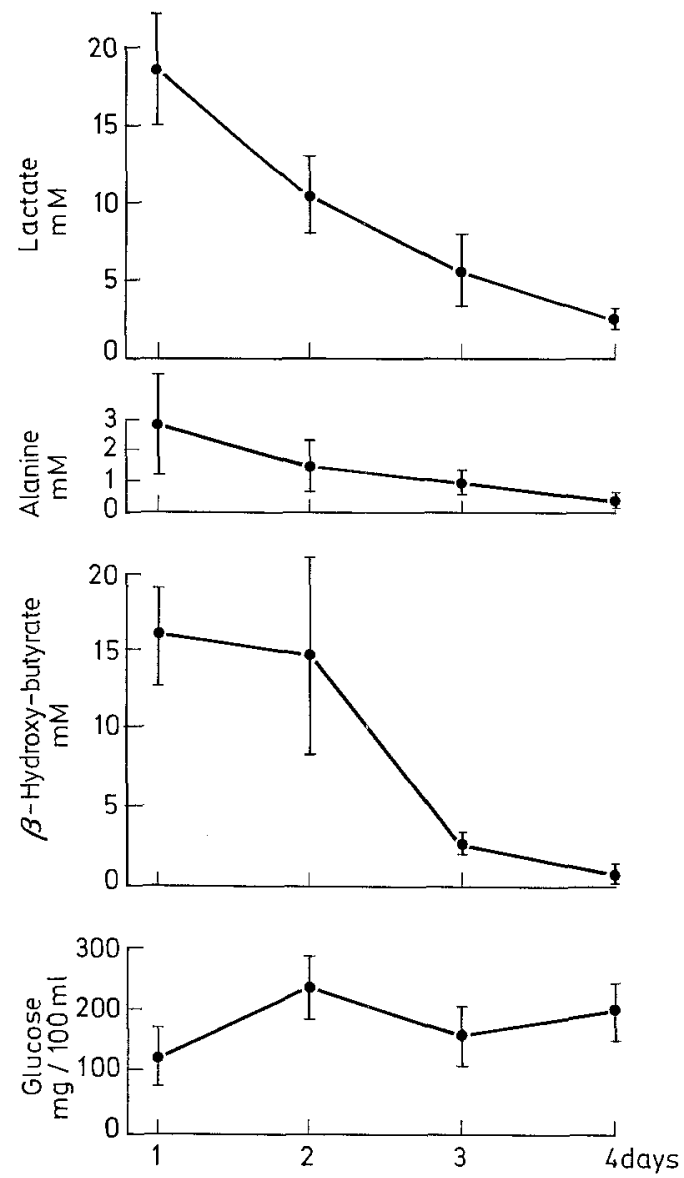

Fig. 2. Time-course for the main circulating metabolites during metformin-induced lactic acidosis. Results are presented as mean \pm SEM

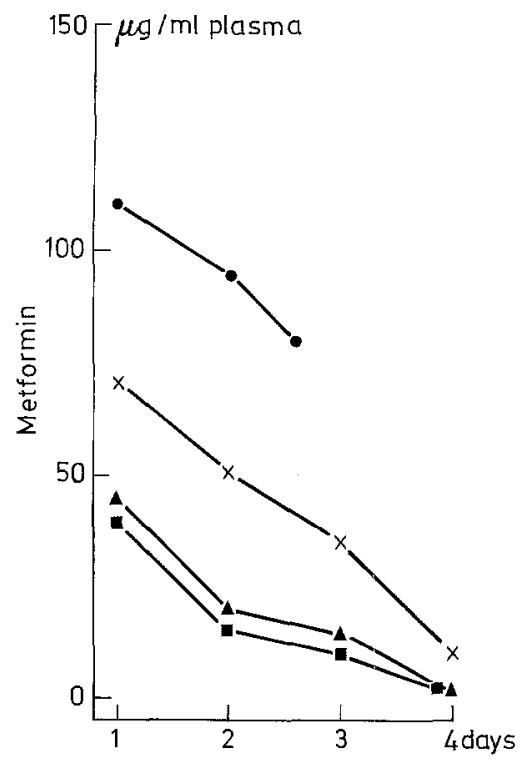

Fig. 3. Plasma metformin level during the therapeutic period in 4 patients with a metformin-induced lactic acidosis. In the patient $\mathrm{n}^{\circ} 2$ metformin was detected in the effluent during peritoneal dialysis, at concentrations of 8 to $12 \mu \mathrm{g} / \mathrm{ml}$. Symbols and curves correspond to patients no. $1(\times)$, no. $2(\Delta)$, no. $3(\boldsymbol{U})$ and no. 5 
to differences in lipophilic properties and binding to the mitochondrial membrane [21-23], but the mechanism of action seems to be basically the same for both drugs [23-29]. The metabolic pattern in the present cases was strikingly identical to that observed in phenformin-associated lactic acidosis [1, 12-16, 30-32] and experimental phenformin-induced lactic acidosis in rats [33]. If differences do exist between metformin and phenformin regarding the frequency of adverse reactions in patients, these may be related to differences in pharmacokinetics rather than mechanism of action.

Metformin is normally very rapidly excreted by the kidney $[34,37]$ and not metabolized at all by the liver, as distinct from phenformin [38-40]. Acute renal failure seems to have played a vital role in the precipitation of lactic acidosis in 5 of our patients and in most of the cases published by others (Table 4). Arteriography, pyelography, i.v. infusion of low molecular weight dextran or large doses of gentamycin, could account for the occurrence of anuria [41-43]. The hypothesis of metformin accumulation seems strongly supported by the experience of patient $n^{\circ} 3$ and by the high concentration of biguanide measured in the plasma from patients $\mathrm{n}^{\circ} 1,2,4,5$; concentration in the liver must have been even higher [34-37]. Acute renal failure may have also reduced the metabolism of lactate by the kidney which, normally, can metabolize up to $30 \%$ of a lactate load [44, 45]. This occurred precisely when hepatic gluconeogenesis and lactate uptake by the liver were impaired under the influence of biguanide accumulation, metabolic acidosis and poor haemodynamic state. It has been known for years that metformin is excreted by the kidney: continuation of metformin treatment in spite of anuria can be accounted for by ignorance of the pharmacokinetics of the drug outside the specialised diabetic clinics. Whether chronic renal failure can favour accumulation of metformin and the triggering of lactic acidosis remains unclear from our case records. However since an elevation of serum creatinine occurred readily in association with acute gastroenteritis or diuretic treatment, etc., the long-term prescription of metformin in such patients seems rather hazardous: a chronic elevation of serum creatinine should be a clear indication for not giving metformin.

The therapeutic management proved efficient since 5 out of 6 patients recovered from the acute metabolic event. Early and massive alkalinization is a possible physiopathological treatment, restoring liver enzymic activities $[44,45]$; this therapy was associated with forced diuresis and dialysis; relatively low amounts of insulin and glucose were administered $[46,47]$. Because of the possible risk of pulmonary hypertension [48], the infusion of large amounts of plasma volume expanders was carried out with concomitant measurements of central venous blood pressure. Two patients died because of secondary vascular complications. Biguanides, as fibrinolytic agents, may be used in patients with impaired cardiovascular and renal status [49]. In such patients, metformin or other biguanides cannot be regarded as mild, harmless drugs. Metformin, like phenformin, buformin [50], formerly synthaline [51 and 52] and occasionally another guanidine derivative, pentamidine or Lomidine ${ }^{\circledR}[53]$, can induce lactic acidosis in the presence of renal failure. It must be emphazised that biguanides should not be used in patients with renal failure and that the treatment of diabetes with intercurrent illness is Insulin.

Acknowledgements. We thank gratefully the authors [6-11] and the Swedish Adverse Drug Reaction Committee who kindly replied to our requests for further information about published case records. We also wish to express our gratitude to Josette Boillot, Pascal Ferré, Jean-Paul Pégorier who contributed to hormone and substrate assays, and the medical and nurse staffs who favoured the serial metabolic study. This work has been subsidised by grants from the Fondation Nationale pour la Recherche Médicale, the Délégation Générale à la Recherche Scientifique et Technique, the Institut National de la Santé et de la Recherche Médicale, the Université Paris VI.

\section{References}

1. Assan, R., Heuclin, Ch., Girard, J. R., Lemaire, F., Attali, J. R.: Phenformin-induced lactic acidosis in diabetic patients. Diabetes 24, 791-800 (1975)

2. Freedman, L., Blitz, M., Gunsberg, E., Zak, S.: Determination of phenformin in biologic fluids and tissues. J. Lab. Clin. Med. 58, 662-666 (1961)

3. Heuclin, Chr., Pene, F., Savouret, J.F., Assan, R.: Characterization of phenformin and metabolites in plasma. Diabète et métabolisme 1, 235-240 (1975)

4. Siest, G., Roos, F., Gabou, J.J.: Dosage du N-N-diméthyl biguanide (glucophage) par le diacétyle en milieu alcalin. Bull. Soc. Pharm. Nancy 58, 29-38 (1963)

5. Pignard, P.: Dosage spectrophotométrique du N-N-diméthyl biguanide dans le sang et l'urine. Ann. Biol. Clin. (Paris) 3-4, 325-333 (1962)

6. Lebacq, E. G., Tirzmalis, A.: Metformin and lactic acidosis. Lancet 1973 II, 314-315

7. Robert, M., Truchet, P., Veyrat, A.: Acidose lactique chez une diabétique traitée par le N-N-diméthyl biguanide. Lyon Méd. 229, 1143-1146 (1973)

8. Hayat, J. C.: The treatment of lactic acidosis in the diabetic patient by peritoneal dialysis using sodium acetate. A report of two cases. Diabetologia 10, 485-487 (1974)

9. Mirouze, J., Mion, C., Beraud, J. J., Selam, J. L.: Acidose lactique à l'occasion d'insuffisance rénale chez deux diabétiques traités par metformine. Nouv. Presse Méd. 5, 1004-1007 (1976)

10. Larcan, A., Lambert, H.: L'acidose lactique. A propos de 42 observations collectées dans un service de réanimation. Journées de Diabétologie de l'Hôtel-Dieu, p. 99-133. Paris: Flammarion Médecine Sciences, Ed. 1976

11. Uvnäs, R.: Biguanides and lactacidosis. Lekartidningen (Stockholm) 70, 3505-3507 (1973) 
12. Gong, W. C., Kato, D. B.: Phenformin induced lactic acidosis: a case report and review of the literature. Drug Intelligence and Clin. Pharm. 9, 236-240 (1975)

13. Searle, G.L., Siperstein, M.D.: Lactic acidosis associated with phenformin therapy; evidence that inhibited lactate oxidation is the causative factor. Diabetes 24, 741-745 (1975)

14. Brach, B.B., Blackard, W., Rothschild, H.: A review of deaths due to suspected lactic acidosis at a large metropolitan hospital. Southern Med. J. 68, 202 (1975)

15. Fulop, M., Hoberman, H.D.: Phenformin associated metabolic acidosis. Diabetes 25, 292-296 (1976)

16. Wise, P.H., Chapman, M., Thomas, D. W., Clarkson, A.R., Harding, P.E., Edwards, J.B.: Phenformin and lactic acidosis. Br. Med. J. 1, 70-72 (1976)

17. Information Medicale et Statistique: 12, A 10-B 69 (1975)

18. Beaser, S. B.: Therapeutic value of biguanides. Clinical results. Diabetes, 1969. In: J. Ostman, R.D.C. Milner (Eds): Proc. 6th Congress Int. Diab. Fed., pp. 764-767. Amsterdam: Excerpta Medica 1969

19. Bergman, U., Elmes, P., Halse, M., Halvorsen, T., Hood, H., Lunde, P. K. M., Sjökvist, F., Wade, O. L., Westerhol, M. B.: The measurement of drug consumption: drugs for diabetes in Northern Ireland, Norway and Sweden. Eur. J. Clin. Pharmacol. 8, 83-86 (1975)

20. Mehnert, H., Haese, E. G.: Biguanide (Klinischer Teil). In O. Eichler, A. Farah, H. Herken, A.D. Welch (Eds.): Handbook of experimental pharmacology, New Series, Band XXIX: H. Maske (Ed.). Berlin, Heidelberg, New-York: Springer 1971

21. Schäffer, G.: Commentary on the mechanism of action of hypoglycemia-producing biguanides. $\mathrm{A}$ reevaluation and a molecular theory. Biochem. Pharmacol. 25, 2005-2014 (1976)

22. Schäffer, G.: Some new aspects on the interaction of hypoglycemia-producing biguanides with biological membranes. Biochem. Pharmacol. 25, 2015-2024 (1976)

23. Toews, C. J., Kyner, J. L., Connon, J. J., Cahill, G. F.: The effects of phenformin on gluconeogenesis in isolated perfused rat liver. Diabetes 19, $368(1970)$

24. Meyer, F., Ipaktchi, M., Clauser, H.: Specific inhibition of gluconeogenesis by biguanides. Nature 213, 203-204 (1967)

25. Cook, D.E., Blair, I. B., Gilfillan, C., Lardy, H. A.: Mode of action of hypoglycemic agents. IV. Control of the hypoglycemic activity of phenethylbiguanide in rats and guineapigs. Biochem. Pharmacol. 22, 2121-2128 (1973)

26. Cook, D.E., Blair, J.B., Lardy, H. A.: Mode of action of hypoglycemic agents. - V. Studies vith phenethylbiguanide in isolated perfused rat liver. J. Biol. Chem. 248, 5272-5277 (1973)

27. Ogata, K., Joamin-Baum, M., Hanson, R.W.: Phenethylbiguanide and the inhibition of hepatic gluconeogenesis in the guinea-pig. Biochem. J. 144, 49-57 (1974)

28. Davidoff, F.: Phenethylbiguanide inhibits mitochondrial $\mathrm{Ca}^{++}$fluxes: a mechanism for inhibition of gluconeogenesis. Diabetes 23 (suppl. 1) 369 (1974)

29. Medina, J.M., Sanchez-Medina, F., Mayor, F.: Effect of phenformin on gluconeogenesis in perfused rat liver. Rev. Esp. Fisiol. 27, 253-256 (1971)

30. Ball, S., Woods, H.F., Alberti, K.G.M.M.: Lactic acidosis, ketoacidosis and hyperalaninaemia in a phenformin-treated diabetic patient. Br. Med. J. 4, 699-700 (1974)

31. Davidson, M. B., Bozarth, W. R., Challoner, D. R., Goodner, C. J.: Phenformin, hypoglycemia and lactic acidosis. N. Engl. J. Med. 275, 886-888 (1966)

32. Medalle, R., Webb, R., Waterhouse, C.: Lactic acidosis and associated hypoglycemia. Arch. Otolaryngology 94, 273-278 (1971)

33. Heuclin, Chr., Attali, J. R., Girard, J. R., Assan, R.: Hyperphenforminemia, renal failure, lactic acidosis; human clinical condition and experimental model in rats. Diabetologia 10, $369(1974)$
34. Beckmann, R.: Über die Resorption und den biologischen Abbau von 1-(beta-phenäthyl)-biguanid (Phenformin). Diabetologia 3, 368-376 (1967)

35. Beckmann, R.: The fate of biguanides in man. Ann. N.Y. Acad. Sci. 148, 820 (1968)

36. Beckmann, R.: Resorption, Verteilung im Organismus und Ausscheidung von Metformin. Diabetologia 5, 318-324 (1969)

37. Cohen, Y., Costerousse, O.: Etude expérimentale du métabolisme du diméthyl-biguanide marqué au Carbone-14. C. R. 4 è Congrès de la Fédération Internationale du Diabète, Genève, 10-14 juillet 1961, p. 745-748. Genève: Editions Médecine et Hygiène 1962

38. Hall, H., Ramachander, G., Glassman, J. M.: Tissue distribution and excretion of phenformin in normal and diabetic animals. Ann. N. Y. Acad. Sci. 148, 601-611 (1968)

39. Murphy, P.J., Wick, A.N.: Metabolism of beta-phenethylbiguanide. J. Pharm. Sci. 57, 1125-1127 (1968)

40. Alkalay, D., Khemani, L., Wagner, W.E., Bartlett, M.: Pharmacokinetics of phenformin in man. J. Clin. Pharmacol. 15, 446-448 (1975)

41. Barshay, M.E., Haye, J.H., Goldman, R., Coburn, J. W.: Acute renal failure in diabetic patients after intravenous infusion pyelography. Clin. Nephrol. 1, 35-39 (1973)

42. Chinitz, J.L., Kim, K.E., Onesti, G., Swartz, C.: Pathophysiology and prevention of dextran-40-induced anuria. J. Lab. Clin. Med. 77, 76-87 (1971)

43. Gingell, J.C., Waterworth, P. H.: Dose of gentamycin in patients with normal renal function and renal impairment. $\mathrm{Br}$. Med. J. 2, 19 (1968)

44. Yudkin, J., Cohen, R. D.: The contribution of the kidney to the removal of a lactic acid load under normal and acidotic conditions in the conscious rat. Clin. Sci. Mol. Med. 48, 121-131 (1975)

45. Cohen, R.D., Simpson, R.: Lactate metabolism. Anesthesio$\operatorname{logy} 43,661-673(1975)$

46. Dembo, A. J., Marliss, E. B., Halperin, M.L.: Insulin-therapy in phenformin-associated lactic acidosis: a case report, biochemical considerations and review of the literature. Diabetes 24, 28-35 (1975)

47. Holloway, P.A., Alberti, K.G.M.M.: Reversal of phenformin induced hyperlactataemia by dichloracetate in normal and diabetic rats. Diabetologia 4, 11 (1975)

48. Fahlen, M., Bergman, H., Helder, G., Ryden, L., Wallentin, I., Zitergren, L.: Phenformin and pulmonary hypertension. Br. Heart J. 35, 824-828 (1973)

49. Fearnley, G. R.: Development of oral fibrinolytic therapy. In: K. N. von Kaulla and J.F. Davidson (Eds.): Synthetic fibrinolytic agents, pp. 305-311. Springfield, Ill.: Ch. C. Thomas 1975

50. Clavadetscher, P., Bischof, P., Wegmann, T.: Lactic acidosis after administration of buformine. Dtsch. Med. Wochenschr. 101, 238 (1976)

51. Minot, A.S., Dodd, K., Saunders, J.M.: The acidosis of guanidine intoxication. J. Clin. Invest. 13, 917-932 (1934)

52. Davidoff, F.: Guanidine derivatives in medicine. N. Engl. J. Med. 289, 141-146 (1973)

53. Marliss, E. B.: Lactic acidosis in an anuric patient treated with pentamidine. (Personal communication)

Received: October 19, 1976, and in revised form:

January 11, 1977

Dr. R. Assan

Department of Diabetology

Hôtel Dieu

1 place du Parvis Notre-Dame

F-75181 Paris Cedex 04

France 